\title{
PALATABILITY AND EFFICACY OF RB SOFT BAG FORMULATED BAITS IN CONTROLLING HOUSE MOUSE AND NORWAY RAT IN ANIMAL FOOD BLENDER FACILITIES AND PIG FARM
}

\author{
M. Vukša ${ }^{1}$, S. Đedović ${ }^{1}$, G. Jokić ${ }^{1}$ B. Stojnić ${ }^{2}$ \\ ${ }^{1}$ Institute of Pesticides and Environmental Protection, Zemun, Republic of Serbia \\ ${ }^{2}$ Faculty of Agriculture, Institute of Phytomedicine, Zemun, Republic of Serbia \\ Corresponding author: Marina.Vuksa@pesting.org.rs \\ Original scientific paper
}

Abstract: The Norway rat and house mouse the most important rodent pest at farms eat and polullut the huge food quantity and carry a range of severe infectious deseases to humans and pets. Rodent control is undertaken only after its presence has been registered. Preparations for their control need to meet palatability requirements. Experiments were conducted in animal food blender facilities and pig farm (maternity and rooms with young and adult pigs) in Omoljica following the standard EPPO method. Palatability and efficacy of RB formulated baits (paste in special $10 \mathrm{~g}$ paper bags) containing $0.005 \%$ bromadiolone and $0.005 \%$ brodifacoum were tested against the house mouse and Norway rat . Baits in pelllete formulation were used as the standard. All the baits were placed in special boxes. Rodent abundance was evaluated based on the highest and the lowest daily baits consumption divided by the daily required of food amount, and a census method before and after treatment. Rodent presence was monitored over the next 20 days. The efficacy of the tested RB soft bag and standard formulations was calculated according to Abbott's formula. The results showed that palatability and efficacy of RB soft bag formulations (81-100\%) was substantially high especially of brodifacoum-based baits. .

Key words: house mouse, Norway rat, RB soft bag formulation, palatability, efficacy, pig farm

\section{Introduction}

House mouse (Mus musculus) is one of the commonest rodent species. It reproduces rapidly. Namely, young females can breed at 6 time per year and produce numerous litters with up to 2000 baby mice a year (Wilson and Reeder, 1992). Mice are omnivorous and may cause significant damage in both household 
and farms. Rats are also among the most distributed rodent species. In Serbia the grey rat (Rattus norvegicus) is the commonest wich couses the serious damage, not only through consumed foood quantitty, an adult rat may eat $10,9 \mathrm{~kg}$ annually, but also through pollution and contamination up to nine time fold more of foood (Kataranovski at al., 1988; Dunđerski at al., 1999; Djukić et al., 2005). Rodents have important epidemic significance as natural source and main vector of pathogens of animal and human origin or indirectly by numerous ectoparasites (Gratz, 1988; Morita, 1995; Stajković at al., 1995; Leirs, at al., 2004; Olumide, 2008; Kyriakis and Alexopulos, 2011). In our country it is recorded several cases of trichinelosis and hemorragic fever wich were quite often ended with death. Two interesting cases were occured on pig farms in Vojvodina in 1995 year. At the one farm died 30, while at the other died 60 tons of rats wich were colllected, mixed with the oil and burned (Radosavljević, 2003).

It is impossible to destroy rodents and for this reason their number should regularly be kept under control. Prior to that their number needs to be evaluated and the species present should be determined using the method of transect $\mathrm{C}-30$ (WHO) (Djukić et al., 2005), i.e. census (EPPO, 1999). According to the HACCP system principles (Kyriakis and Alexopulos, 2011) strategy should be used to prevent damages due to rodent activity that includes several measures.

Preventive: agricultural practices, technological, manipulative, sanitary, hygienic, constructional, technical. Direct: mechanical, physical, biological, genetic and chemical methods. Mechanical: Application of different traps (baits, glues) (Leirs et al., 2004; Singleton et al., 2004; Olumide, 2008). Biological: Use of parasites, prey birds or pathogenous microorganisms. However, caution is needed because accidental poisoning of man and useful organisms is not excluded (Рилников and Тошигин, 1990.). Chemical Control: The rodenticides mostly used contribute to the most efficient and rapid reduction of overpopulated rodent pests. This is not always justifiable from the biological standpoint, especially acute rodenticides which provoke rapid death and hostility towards the bait offered, changes in the behaviour of the rodent, danger to non-target animals, man and the evironment (Claperton, 2006; Fisher, 2006). There is no ideal rodenticide toxic to rodents only and non-toxic to animals and man. For this reason there is a big choice of rodenticides differing with regard to chemical composition, mode of action and toxicity (Almaši, 2004; Vukša, 2008). Anticoagulant rodenticides of the first and second generation with the mode of action based on preventing the factors of blood coagulation are mostly used, and lethality is registered after a couple of days only. In the study conducted by Quy et al., a decrease in the palatability and efficacy of bromadiolone, difenacoum and brodifacoum baits was registered (Quy et al., 1992). Therefore, it is necessary to develop acceptable preparations meeting palatability requirements that would stimulate rodents to choose baits rather than other food available in abundance in storehouses, prevent any hostility, protect non-target organisms and the environment . 


\section{Materials and Methods}

Harmful species. Domestic mouse (Mus musculus) and Gray - Norway rat (Rattus norvegicus)

Localities. Experiment with R.norvegicus was conducted at rooms with adult pigs, dimensions that were $40 \times 100 \mathrm{~m}$, in pig farm "OMO RATAR", Omoljica and encompasses the surrounding area with active rodent holes.

Refferent examinations were conducted in maternity dimensions that was $50 \times 30$ $\mathrm{m}$, lavatory room dimensions that was $5 \times 6 \mathrm{~m}$ and rooms with piglets dimension that were $5 \times 7 \mathrm{~m}$.

Experiment with Mus musculus in animal food blending facility pig farm "OMO RATAR", Omoljica dimension that was 490 × $30 \mathrm{~m}$ with blending machines and electrical installations.

Refferent examinations for Mus musculus were conducted in storage of animal food blending facility dimension that was $20 \times 30 \mathrm{~m}$ with food stored in sacks lifted up on pallets.

Preparation studied. Palatability and efficacy of the following preparations was studied:

- Brodifacoum-based active substance BRODY FRESH BAIT $(0,005 \%$ brodifacoum) manufactured by KOLLANT, Italy, represented in Serbia by MAGAN YU, Subotica. Referent preparation applied was RATTACK-pellets $(0,005 \%$ brodifacoum $)$ produced by DUOCHEM, Belgrade, Serbia.

- Bromadiolone-based active substance: RATIBROM 2 FRESH BAIT manufactured by KOLLANT, Italy, represented in Serbia by MAGAN YU, Subotica; GARDENTOP manufactured by ZAPI, Italy, represented in Serbia by AGROMARKET, Kragujevac; GLODACID PLUS manufactured by UNICHEM, Slovenia, represented in Serbia by PALPROPROM, Batajnica, Serbia and BRODILON MEKI MAMAC (BRODILON SOFT BAIT) manufactured by VETERINA, Kalinovica, Croatia. All preparations had 0,005\% bromadiolone as active substance. Referent preparation was pellet formulation $(0,005 \%$ bromadiolone) HeMus AB produced by HEMOVET, Novi Sad,Serbia.

All the tested preparations were formulated as RB (ready to use) soft bait paste kept in special $10 \mathrm{~g}$ paper bags.

Trial methods. The trial complied with the PP 1/114(2) method $(O E P P / E P P O, 1999)$. Rodent abundance was assessed using the C-30 method (World Health Organization) or the transect method (EPPO, 1990; EPPO, 1992) at the beginning and 10 days after the beginning of the trial. Rodent abundance was evaluated based on the highest and lowest daily food consumption of baits over a 10 day trial period divided by the daily required amount of feeding. Placebo bait was laid at 10 spots in each facility over a period of 5 days.

At the allfarm facilities and the animal feed blending facility, on places where rodent activity had been observed previously and along rodent paths 
(underneath pellets), tested and referent baits were placed in special boxes for bait exposition at 1-3 m intervals, one bag (10 g) for mice (Mus musculus) and three to five (30-50 g) for rats (Rattus norvegicus). Each box was marked with labels (with serial number), amount of preparation in $(\mathrm{g})$ and the date of experiment. The duplicate of each label was sticked on the wall above the box, at the visible place, with warning elements according the HACCP standard regulations (Bokelman, 1996).

Tested and standard baits were placed directly at the active holes, in amount of 3-5 bags (30-50 g), for Norway - grey rat found around the farm.

Effect mark. The control of bait consumption was daily conducted within 10 consecutive days. Rodent presence was monitored over the next 30 days.

Statistical methods. The palatability and efficacy of the tested RB soft bait and standard formulations was calculated according to Abbott's (1925.) and Handerson-Tilton's (1955.) formula.

Rodenticides application. In the experiment in rooms with adult pigs 14 boxes with tested baits in amount of 3-5 bags (30-50 g) were placed at the distance of 2-3 m against Rattus norvegicus. The boxes were placed along the wals and the room doors to prevent pigs contact with preparation. Baits were also placed in the active holes along the outdoor wals of pigsty (pen).

In the refferent experiments against Rattus norvegicus at the maternity were placed 15 boxes with 3-5 bags (30-50 g) of RATTACK pellets at the distance of $3-5 \mathrm{~m}$. At the maternity lavatory and rooms with piglets were placed 14 boxes at the distance of 2-3 m with 3-5 bags (30-50 g) of refferent bait HeMus AB.

In the animal food blending facility were placed 15 boxes with one bag $(10 \mathrm{~g})$ of tested preparations at the distance of 2-3 m.

In the refferent experiment against Mus musculus in the storage of the animal food blending facility were placed 10 boxes with 1 bag (10 g) HeMus AB.

\section{Results and Discussion}

Palatability and efficacy of the preparations studied. Table 1 . shows the overall bait consumption, evaluated abundance of house mouse (Mus musculus) and Norway-grey rat (Rattus norvegicus) (at the start and at the end of trial) and efficacy in rodent control of standard and tested RB soft bait preparations on the basis of bromadiolone. 
Table 1. Amount of bait on the basis of bromadiolone taken (g), rodent numbers and rodenticide efficacy in food blender facility and pig farm

\begin{tabular}{|c|c|c|c|c|c|}
\hline \multirow{2}{*}{$\begin{array}{l}\text { Preparation } \\
\text { (active substance bromadiolone) }\end{array}$} & \multirow{2}{*}{ Species } & \multirow{2}{*}{$\begin{array}{l}\text { Bait taken } \\
(\mathrm{g})\end{array}$} & \multicolumn{2}{|c|}{ Estimated number } & \multirow{2}{*}{$\begin{array}{l}\text { Efficacy } \\
\%\end{array}$} \\
\hline & & & Begining & End & \\
\hline \multirow{2}{*}{$\begin{array}{l}\text { HeMUS AB } \\
\text { (standard bait -pellets) }\end{array}$} & R. norvegius & 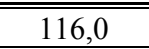 & 8 & $\overline{1}$ & 997,50 \\
\hline & M. musculus & 56,5 & 8 & 0 & 100,00 \\
\hline \multirow{2}{*}{$\begin{array}{l}\text { BRODILON MEKI MAMAC } \\
\text { (RB SOFT BAIT) }\end{array}$} & R. norvegicuss & 422,0 & 11 & 2 & 81,81 \\
\hline & M. musculus & 356,0 & 37 & 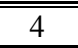 & 89,20 \\
\hline \multirow{2}{*}{$\begin{array}{l}\text { RATIBROM } 2 \text { FRESH BAIT } \\
\text { ( RB SOFT BAIT) }\end{array}$} & R. norvegicus & 491,0 & 10 & 2 & 80,00 \\
\hline & M. musculus & 306,0 & 12 & 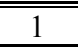 & 91,66 \\
\hline \multirow{2}{*}{$\begin{array}{l}\text { GARDENTOP } \\
\text { (RB SOFT BAIT) }\end{array}$} & R. norvegicus & 197,0 & 6 & 1 & 90,00 \\
\hline & M.musculus & 250,0 & 25 & 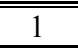 & 96,00 \\
\hline \multirow{2}{*}{$\begin{array}{l}\text { GLODACID PLUS } \\
\text { (RB SOFT BAIT) }\end{array}$} & R. norvegicus & 1950,0 & 49 & 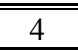 & 91,83 \\
\hline & M.musculus & 244,5 & 25 & 1 & 996,00 \\
\hline
\end{tabular}

The results showed high palatability of all the tested RB soft bait formulated preparations for house mouse (Mus musculus) and Norway-grey rat (Rattus norvegicus) compared with the referent pellet formulated preparation.

Our results showed high values $(80, .00$ do $97,50 \%)$ of all the tested RB soft bait preparations for the Norway-grey rat (Rattus norvegicus) control and very high efficacy (91,60 do $100 \%$ ) for the house mouse (Mus musculus) control.

The overall bait consumption, evaluated abundance of house mouse (Mus musculus) and Norway-grey rat (Rattus norvegicus) (at the start and at the end of trial) and efficacy in rodent control of standard and tested RB soft bait preparation on the basis of brodifacoum are shown in Table 2.

Table 2. Amount of bait taken (g), rodent numbers and rodenticide efficacy in food blender facility and pig farm

\begin{tabular}{||l||c||c||c|c||c||}
\hline \multirow{2}{*}{$\begin{array}{l}\text { Product (active substance } \\
\text { brodifacoum) }\end{array}$} & \multirow{2}{*}{ Species } & \multirow{2}{*}{$\begin{array}{c}\text { Bait taken } \\
(\mathrm{g})\end{array}$} & \multicolumn{2}{|c||}{ Estimated number } & \multirow{2}{*}{$\begin{array}{c}\text { Efficacy } \\
\%\end{array}$} \\
\cline { 5 - 7 } & & & Begining & End & \\
\hline \hline $\begin{array}{l}\text { BRODY FRESH BAIT } \\
\text { (RB SOFT BAIT) }\end{array}$ & R.norvegicus & 468,5 & 13 & 0 & 100 \\
\cline { 2 - 6 } & M. musculus & 70,0 & 14 & 0 & 100 \\
\hline \hline $\begin{array}{l}\text { Rattack pelets } \\
\text { (standard baits) }\end{array}$ & R.norvegicus & 372,5 & 8 & 0 & 100 \\
\cline { 2 - 6 } & M. musculus & 37,5 & 9 & 0 & 100 \\
\hline
\end{tabular}

The results showed higher overall bait consumption of the tested Brody Fresh Bait preparation compared with the referent Rattack pellet preparation. 
The Brody Fresh Bait preparation showed exceptional efficacy in both house mouse (Mus musculus) and Norway-grey rat (Rattus norvegicus) control.

Our trial results showed exceptional palatability of all the RB soft bait formulated prepations based on bromadiolone and brodifacoum as active substances.

The efficacy of tested bromadiolone-based preparations was extremly high (outstanding) (81,81 to $100 \%$ ), for the brodifacoum-based preparation was $100 \%$ against Rattus norvegicus to $98.50 \%$ against Mus musculus .

Based on some literature data (Parshad et al, 1987.), products based on bromadiolone and brodifacoum were found to demonstrate $80.8-97 \%$ efficacy against house mouse on poultry farms.

According to Rowe et al. (1978) brodifacoum efficacy against house mice on farms ranged from $92.7 \%$ to $100 \%$ (mean 98.8\%). Bromadiolone efficacy against the same farm pest ranged from $92.7 \%$ to $100 \%$ (mean $92.4 \%$ ) in another trial (Rowe et al., 1981).

Our results in efficacy testing of products on the basis of bromadiolone and brodifacoum against house mouse (Mus musculus) and Norway-grey rat (Rattus norvegicus) are in accordance with those reported by other authors (Rowe et al., 1981; Parshad et al., 1987; Brooks and Rowe 1987; Quy, 1992; Milić, 1999; Vukša et al., 2002; Leirs at al., 2004; Vukša 2008).

\section{Conclusion}

The Norway- grey rat (Rattus norvegicus Berk.) and house mouse (Mus musculus L.) are the most important pest rodents in food blender facilities and farms. It is very important to follow their abundance during the year and maintain it at the acceptable level, avoid losses and damage of storage facilities and prevent disease transmission.

To suppress rodents and maintain their number at the sustainable level is a delicate task and chemical control mesures are usually required.

The choice of baits should be given special attention considering rodents to be very intelligent and prudent animals but also the need to prevent environmental pollution. Baits which do not provoke fear and hostility (on the basis of anticoagulation active substances) and avoid environmental contamination should be applied .

Our investigation shows that the new RB soft bait formulation of rodenticide has exceptional palatability for both rodent species (Rattus norvegicus and Mus musculus) of major importance in storage facilities and outstanding efficacy of their control. It is also very convenient being packed in special paper bags which do not allow spilling and food and environmental contamination. 


\title{
Acknowledgment
}

This study was carried out as a part of project III 4608 «Development of integrated menagment system harmful organisms in plant aiming to overcome resistance and improve food qyality and safety» wich is financiallz supported bz Ministry of Education and of Science of the Republic Serbia.

\section{Prihvatljivost i efikasnost RB mekog mamka formulacije u suzbijanju kućnog miša i sivog pacova u mešaoni stočne hrane i na farmi svinja}

\author{
M. Vukša, S. Đedović, G. Jokić, B. Stojnić
}

\section{Rezime}

Suzbijanje glodara vrši se uglavnom po uočavanju brojnog prisustva. Preparati treba da imaju što bolju prihvatljivost.

Eksperimente smo obavili u mešaoni stočne hrane i na farmi svinja (obori sa odraslim svinjama, porodilište i prostorije sa malim prasićima) u Omoljici po standardnoj EPPO metodi. Prihvatljivost $\mathrm{i}$ efikasnost RB formulisanih mekih mamaka (u obliku paste u kesicama mase $10-20 \mathrm{~g}$ ) sa $0,005 \%$ bromadiolona $\mathrm{i}$ $0,005 \%$ brodifakuma kao aktivne supstance su testirani za suzbijanje kućnog miša i sivog pacova. Kao standard koristili smo mamke u obliku peleta. Mamci su postavljani u specijalne kutije. Brojnost glodara izračunata je na osnovu najveće i najmanje količine pojedenog mamka podeljeno sa dnevnom količinom potrebne hrane, a primenjen je metod cenzusa pre i posle tretmana. Prisustvo glodara praćeno je i 30 dana posle tretmana. Prihvatljivost i efikasnost testirane RB (meki mamak) i standardne formulacije izračunata je prema Abott-ovoj i Handers-Tiltonovoj formuli.. Rezultati su pokazali da je postignuta veoma visoka prihvatljivost testirane $\mathrm{RB}$ formulacije naročito za mamke na bazi brodifakuma kao aktivne supstance. Efikasnost svih testiranih preparata na bazi bromadiolona bila je izuzetno visoka, 81,81 do $100 \%$, a za preparat na bazi brodifakuma iznosila je 100 $\%$ i za Rattus norvegicus i za Mus musculus.

\section{References}

ABBOTT W.S. (1925): A method of computing the effectiveness of an isecticide. J. Econ. Entomol., 18,265-267.

ALMAŠI R. (2004): Glodari u skladištima, 314-320, Biljni Lekar, 3-4, N. Sad. 
BOKELMAN B. (1996): Quality Assurance and HACCP with Special Attention to Long Life Products.

BROOKS E.J., ROWE P.F. (1987): Commensal rodent control. World Health Organization, WHO/VBC/87.949.

BROOKS J.E., FIELDER L.A (2006): Vertebrate Pests: Demage of stored products (Majia D., ed). AGSI/FAO.

CLAPERTON B.K (2006): A Rewiew of the Current knowledge of rodent behaviour in relation to control devices. Science \& Techical Publishing, Department of Conversation, Wellington, New Zealand.

EPPO (1990): Guidline on design and analysis of efficacy evaluation trials.No. 152, EPPO Bull., 20, 551-579.

EPPO (1992): Guide for the efficacy evaluation of rodenticides, No.169, EPPO Bull., 22, 181-202.

EPPO (1999): Guideline for the efficacy evaluation of rodenticides: Field tests against synanthropic rodents (Mus musculus, Rattus norvegicus i R. rattus) - PP 1/114(2), in EPPO 1999. Guidelines for the efficacy evaluation of Plant Protection Products. Rodenticides, 1, European and Mediterranean Plant Protection Organization, Paris, pp. 83-144.

DUNĐERSKI Z., KAPLANOVIĆ S., MATIĆ R., MAHOVIĆ M. (1999): Procena brojnosti populacija glodara u Beogradu tokom 1998/1999 godine. Zbornik radova III beogradske konferencije o suzbijanju štetnih artropoda i glodara. 219226. Beograd.

ĐUKIĆ N., HORVATOVIĆ A., KATARANOVSKI D., MALETIN S., MATAVULJ M., PUJIN V., SEKULIĆ R. (2005): U knjizi: Poljoprivredna zoologija sa ekologijom, I Filozofija prirode, opšta zoologija i sistematika Životinja; Poljoprivredni fakultet Novi Sad, 524-528.

GRATZ N.G (1994): Rodents and humane disease: a global appretiation. In: Prakash, I. - Rodent and Pest Menagment, CRC Press, Inc. Boca Raton, Fla, USA. HENDERSON C.F., TILTON E.W. (1955): Test with acaricides against Brown mite, J.Econ. Entomol., 48,157-161.

KATARANOVSKI D., SAVIĆ I., JOVANOVIĆ T., VUKIĆEVIĆ O (1988): Ekonomski značaj štetnih glodara i osvrt na preliminarna istraživanja šteta koje nanose glodari u Beogradu. Zbornik radova Prve beogradske konferencije o suzbijanju štetnih artropoda i glodara, Beograd, str. 119-125.

KYRIAKIS S.C., ALEXOPOULOS C. (2011): Preventive vetrinary medicine and hygiene on-farm strategies for the assurance of safety and quality in pork production. Sustainable Animala Production.

LEIRS H., LODAL J., KNORR M. (2004): Factors correlated with the presence of rodents on outdoor pig farms in Denmark and suggestions for menagment strategies, NAAS 52-2, 145-162. 
MILIĆ LJ. (1999): Primena devitox mamaka za deratizaciju u prehrambenoprerađivačkoj industriji.X jubilarno savetovanje DDDDD u zaštiti životne sredine, Aranđelovac, 122-128.

MORITA C.H., MATSUURA Y., MORIKAWA S.H., KITAMURA T. (1985): Age dependent transmission of hemoragic fever with renal syndrome (HFRS) virus in rats. Arch. Virol., 85, 145, 1985.

OLUMIDE A.A. (2008): A study on wild rar behaviour and control on a pig farm. Master of Science Programme in Veterinary Medicine for International Students, Faculty of Veterinary Medicine and Animal Sciences Uppsala.

PARSHAD V.R., AHMAD N., CHOPRA G. (1987): Deterioration of poultry farm environment by commensal rodents and their control. International Biodeterioration, 23, 29-46.

RADOSAVLJEVIĆ M. (2003): Sivi pacov je veoma opasan glodaar, Poljoprivrednik, Poljoprivreda, info.

ROWE F.P., SWINNEY T., PLANT C. (1978): Field trials of brodifacoum (WBA 8119) against the house mouse (Mus musculus L.). Journal of Hygiene, Cambridge, 81, 197-201.

ROWE F.P., PLANT C.J., BRADFIELD A. (1981): Trials of the anticoagulant rodenticides bromadiolone and difenacoum against the house mouse (Mus musculus L.).Journal of Hygiene, London 81, 171-177.

РЫЛЫИКОВ В.А., ТОШИГИН Ю.В. (1990): Методы богъбы с серыми крыеами. У: СОКОЛОВ, В.Е., КАРАСЕВА, Е.В. (Ред), Серая крыса, Систематика , Экологія, Регулясия численности, АН СССР, Изд. "Наука", Мосkва, 360.

QUY R.J., SHEPERD D.S., INLIS I.R. (1992): Bait avoidance and effectiveness of anticoagulant rodenticides against warfarin- and difenacoum-resistent populations of Norway rats (Rattus norvegicus). Crop Protection, 11, 14-20.

SINGLETON C.R., BROWN P.R., JACOB J. (2004): Ecologically-based rodent menagment: its effectiviness in cropping systems in South Asia, NJAS 52-2, 163-172. SHAFI M.M., AHMED S.M., PERVEZ A., AHMAD S. (1992): Enhancement of poison bait acceptance through taste additives in Rattus norvegicus. Journal of Stored Products Research 28, 239-243.

STAJKOVIĆ N., OBRADOVIĆ M., MILJANOVIĆ Z. (1995): Glodari rezervoari infektivnih agenasa. Zbornik radova VI simpozijuma „DDD u zaštiti životne sredine", Donji Milanovac, str. 114-122.

VUKŠA M., ĐEDOVIĆ S., DRAGANIĆ M., DRAGOJLOVIĆ M. (2002): Ispitivanje palatabilnosti i efikasnosti mamaka DETRIN-KH (formulacije GB i BB) na bazi vitamina D3 u laboratorijskim uslovima i komunalnoj higijeni, Zbornik radova XIII Savetovanja DDD u zaštiti životne sredine (sa međunarodnim učešćem), Kikinda, 179-189. 
VUKŠA M. (2008): Glodari u skladištima i njihovo suzbijanje. U: Zaštita uskladištenih biljnih

proizvoda od štetnih organizama (P. Kljajić), Ed. Institut za pesticide i zaštitu životne sredine, Beograd-Zemun.

WILSON D.E., REEDER D.M. (1992): Mammal Species of the world - a taxonomic and geographic reference. Second edition, Smitshonian Institution Press, 1-1207. Washington and London.

Received 30 June 2011; accepted for publication 15 August 2011 